\title{
REVELIA E PERSUASÃO RACIONAL DO JUIZ
}

\section{DEFAULT AND RATIONAL PERSUASION OF THE JUDGE}

\author{
André Ricardo Vier Botti" \\ Lourival José de Oliveira"
}

\begin{abstract}
Resumo: Verifica os limites da presunção dos fatos contidos na petição inicial quando da ausência de contestação tempestiva e com a observância das formalidades legais. Vista como um fato objetivo, a revelia ocorrerá quando o réu queda-se inerte no momento processual em que lhe é facultado aduzir suas razões de resistência à demanda do autor, o que não implica necessariamente na sua procedência. Contudo, a revelia nem sempre desencadeia os seus efeitos, que são classificados como materiais ou processuais e consistem na presunção de veracidade dos fatos afirmados pelo autor na petição inicial e na desnecessidade do revel ser intimado dos atos processuais subseqüentes, respectivamente. A presunção na revelia é relativa, isto é, os seus efeitos se circunscrevem aos fatos verossímeis e coerentes com as demais provas encartas aos autos, o que se coaduna com a necessidade de direção material e não apenas formal do processo pelo juiz, como forma de encontrar a justa composição do litígio, atendendo, então, as finalidades sociais do processo inserido efetivamente no Estado Democrático de Direito. Conclui que deverá ser exteriorizada na fundamentação da decisão a coerência das bases fáticas e jurídicas, abrangendo todos os pontos relevantes da lide, atendendo, assim, ao princípio da persuasão racional e resultando numa tutela jurisdicional completa, sob pena de nulidade do processo ante a insuficiência de motivação da sentença.
\end{abstract}

\footnotetext{
"Artigo extraído da Dissertação de Mestrado, apresentada ao Programa de PósGraduação Stricto Sensu da Universidade Estadual de Londrina, de autoria do primeiro sob a orientação do segundo.

"* Mestre em Direito Negocial na Universidade Estadual de Londrina-Pr, área de concentração em Direito Processual Civil.

Doutor em Direito pela Pontifícia Universidade Católica de São Paulo.
} 
Palavras-chave: Revelia, Juiz Diretor Material do Processo, Persuasão Racional do Juiz.

\begin{abstract}
It checks the borders of the presumption of facts contained in the initial petition when lacks seasonable contestation with the observance of the legal formalities. Seen as an objective fact, the default will occur when the defendant stays inert at the processual moment offered to him to adduce his reasons to resist the request of the prosecutor, what doesn't necessary implies in its procedure. However, the default not always unleashes its effects, that are classified as material or processual, consisting in the presumption of the veracity of facts pleaded by the prosecutor in his initial petition and the lack of need of notification the default for the processual acts that follows. The presumption in default is relative, it means that, its effects circumscribing verisimilar facts and consistent with the other evidences that lie in the lawsuit, what goes to the need of the material direction and not only the formal side by the judge as a way to find the fair composition of the litigation, there so attending the social finalities of the process effectively inserted in the Democratic State of Law. Coming to the conclusion that shall be exteriorized in the explaining of the decision the coherence of fatidic bases and juridical ones, containing all the prominent points of the suit, therefore attending the principle of the rational persuasion, resulting in a full jurisdictional tutelage, under the penalty of nullity of the law suit due to the lack of motivation of the sentence.
\end{abstract}

Key-Words: Default, Material Managing judge of the Process, Rational Persuasion of the Judge.

\title{
1 INTRODUÇÃO
}

O processo visa à satisfação de uma pretensão resistida, cuja demanda é o instrumento para exigir que a tutela jurisdicional atue, formulando uma norma jurídica concreta e individual para o caso, o que culmina com a pacificação do conflito.

Aduzir uma pretensão em Juízo significa pedir a prolatação de um provimento jurisdicional que substituirá os sujeitos em conflito para eliminar a resistência do demandado, já que foi vedada a autotutela.

Também o demandado formula sua demanda, ao apresentar a defesa, postulando a declaração de que sua resistência é justificada, o 
que significa, a contrário senso, o pedido de improcedência da demanda inicial.

A resposta é a oportunidade para que o demandado aduza as razões da sua resistência à pretensão do demandante. $\mathrm{O}$ autor quer que a resistência do réu seja declarada injustificada e cesse. Por seu turno, o réu pretende a declaração de que é justa a sua oposição.

O binômio demanda e resposta é a premissa da direção contrária dos interesses dos demandantes, representando a bilateralidade do processo, já que a cada demanda inicial ou incidental do demandante existirá a correspondente pretensão do demandado.

Observa-se, então, que a posição de demandante é apenas uma questão de oportunidade e agilidade, pois tanto o demandante quanto o demandado possuem uma pretensão resistida a ser apresentada para solução pelo Estado-Juiz, sendo que aquele que primeiro protocolar sua demanda junto ao órgão jurisdicional assumirá a posição de demandante.

Assim, tal qual ao demandante não se obriga deduzir sua pretensão em juízo, tanto que a jurisdição é inerte e aguarda a sua provocação, não é exigido ao demandado que se discorde da demanda a qual está sendo submetido.

A finalidade do processo é a pacificação e não fomentar a discórdia. Daí, a legislação processual contenta-se em oportunizar que o demandado se manifeste quanto à demanda do autor, o que pode se dar pela inércia, aquiescência à pretensão exposta, apresentação de defesa ou mesmo com a formulação de nova pretensão via reconvenção.

Destarte, não há que se negar que a postura do demandado lhe acarretará efeitos na sua órbita jurídica, cabendo a ele a escolha pela conduta mais conveniente, apesar das conseqüências da mesma serem impostas pela legislação, coercitivamente.

Contudo, na constante busca pela verdade material, atualmente, incumbe ao Juiz se cercar dos instrumentos legais para a busca do justo, não como mero espectador do processo, compatibilizando os poderes dispositivos das partes com os seus poderes instrutórios, assumindo uma postura ativa na relação jurídica processual, revelandose diretor material do processo.

Após a provocação da jurisdição, a justa solução da demanda não mais interessa apenas as partes, mas sim a toda sociedade, que representada pelo Poder Judiciário erradicará o conflito. 
Resta ultrapassado o modelo processual onde a neutralidade total do juiz era fator primordial para a garantia do justo, com o predomínio do interesse das partes, cabendo ao Judiciário apenas aplicar a lei. Atualmente, a postura ativa do Estado-Juiz vem consagrar a isonomia substancial.

Ora, o não atendimento pelo réu ao chamando judicial para integrar efetivamente a relação jurídico-processual, aduzindo as razões da sua resistência na forma e prazo estabelecidos pela legislação processual, apesar de acarretar a revelia, não implica na automática procedência do pedido do autor.

Embora na revelia, via de regra, ocorra à presunção de veracidade dos fatos alegados pelo autor, ante a não satisfação do ônus de apresentar defesa pelo revel, o juiz não pode ficar alheio à realidade fática. O magistrado não pode aceitar absurdos decorrentes da presunção, devendo limitá-la à relatividade que a cerca.

Para se atingir um juízo de valor na revelia, consentâneo com a realidade material, com o deferimento à parte da exata medida do direito que lhe incumbe, somente serão tidos como verdadeiros os fatos aduzidos pelo autor, face o revel, depois de aquilatados pelo juiz com o binômio da verossimilhança e credibilidade, bem como as demais provas encartadas no processo.

A revelia visa à celeridade processual e não uma abstrata punição do revel, já que, nos dizeres de Cândido Dinamarco, "a revelia não é mais tratada como rebeldia, como em tempos idos, nem o efeito da revelia pode ser encarado como pena, mas simplesmente como expediente aceleratório do processo" (2000, p. 951).

A relativização dos efeitos da revelia significa não admitir fatos impossíveis ou inverossímeis, dos quais o Estado-Juiz, na condução do processo, em busca da verdade material, deve exigir a prova de quem fez as alegações. Não há que se deixar de reconhecer e aplicar a revelia, apenas limitar o seu alcance, imputando o ônus probatório do extraordinário (fato constitutivo do direito da parte), já que o corriqueiro realmente se presume.

A verificação dos fatos alegados, pelo sistema probatório, não pode mais integrar o monopólio das partes, sendo necessária à determinação de provas ex oficio pelo Estado-Juiz, nos precisos termos do artigo 130 do Código de Processo Civil Brasileiro, independentemente da disponibilidade ou não da relação jurídica material. 
O objetivo é restaurar a integralidade do Ordenamento Jurídico, mesmo na revelia, por meio de um processo efetivo, que vai além da solução ágil da demanda para alcançar, também, a justa composição do conflito, o que acarreta na credibilidade e certeza de justiça pela sociedade, fins colimados pelo Estado Democrático de Direito.

\section{DA REVELIA: Relativização da Revelia; Intervenção do Revel no Processo; Iniciativa Probatória e Prova na Revelia}

\subsection{Relativização da revelia}

Apesar de se verificar a revelia, vista como fato objetivo do não atendimento ao chamado judicial na forma e prazo fixados, nem sempre os seus efeitos ocorrem, restando relativizados em determinadas hipóteses.

O próprio Código de Processo Civil ${ }^{1}$ arrolou algumas situações em que há a revelia (ausência de defesa), mas não os seus efeitos.

Além, das hipóteses elencadas no artigo 320 do Código de Processo Civil, que são meramente exemplificativas e não exaustivas, pode-se encontrar no próprio texto legal outros óbices aos efeitos da revelia, quais sejam: nomeação de curador especial ao réu citado por edital ou com hora certa que deixou de contestar a ação (artigo 9a do Código de Processo Civil); apresentação de contestação pelo assistente simples do revel (artigo 52, parágrafo único do Código de Processo Civil); ou se o réu apresentar apenas outro tipo de resposta (reconvenção, por exemplo), a qual, tomada em seu conjunto, é incompatível com a presunção de veracidade.

Contudo, a relativização dos efeitos da revelia não está circunscrita às hipóteses legais, vez que a própria finalidade do processo é encontrar uma justa solução para o conflito, sendo que "quando a adoção da revelia ou de seus efeitos puder trazer prejuízo à própria aplicação da

\footnotetext{
${ }^{1}$ Artigo 320 do Código de Processo Civil: "A revelia não induz, contudo, o efeito mencionado no artigo antecedente: I - se, havendo pluralidade de réus, algum deles contestar a ação; II - se o litígio versar sobre direitos indisponíveis; III - se a petição inicial não estiver acompanhada do instrumento público, que a lei considere indispensável à prova do ato.”
} 
justiça, não deve ser acolhida e por isso não gera efeitos contra o revel” (SOUZA, 1995, p. 195).

Com o passar dos anos, porém, restou cristalino o entendimento de que a mentira processual não pode gozar de proteção, que o magistrado não deve se contentar com a verdade formal, mas deve ir em busca da verdade real, no sentido de que o juiz deve ser um participante no processo, deve estar convencido de que o fato constitutivo do autor está definitivamente provado e não por presunção deva ser admitido, como verdadeiro. Assim, no decorrer de anos vem se mitigando esta penalidade imposta, pelo legislador, ao revel de tal forma que hoje nos dedicamos ao estudo dos limites que devem ser impostos ao juiz na absolvição do 'delinqüente' (GIANESINI, 2003, p. 223).

Considerando a unidade do Ordenamento Jurídico, mesmo na revelia, efetivamente a realidade vivenciada no direito processual não pode distanciar-se do direito material, que deve servir como um instrumento de justiça e não de descrédito do Judiciário.

O que a lei quer é fazer com que o processo cumpra rapidamente suas funções sociais e, portanto, não está disposta a se sujeitar a esperas indeterminadas, sancionando, por isso, a omissão, embora não chegue a ponto de querer distorcer o sentido de justiça e o sentido de instrumentalidade do processo (GIANESINI, 2003, p. 223).

Destarte, no procedimento sumário do processo de conhecimento a revelia é fruto da falta injustificada de comparecimento do réu à audiência, reputando-se verdadeiros os fatos alegados na petição inicial, "salvo se o contrário não resultar da prova dos autos", ${ }^{2}$ ressalva que não é feita expressamente no procedimento ordinário.

Mas, vendo o processo de conhecimento como uma unidade sistêmica, não faria sentido tratar a revelia com dimensões diferentes (WAMBIER; ALMEIDA; TALAMINI, 2002). Assim, "em se tratando de procedimento ordinário, tanto quanto no procedimento sumário, ocorrendo a revelia, reputam-se verdadeiros os fatos

${ }^{2}$ Artigo 277, § 2 $2^{\underline{a}}$ do Código de Processo Civil. 
afirmados pelo autor, salvo se o contrário não resultar da prova dos autos” (ALVIM, 2002).

Toda presunção não pode ser vista de maneira absoluta, mas sim dentro da relatividade que a cerca, já que a veracidade dos fatos afirmados pelo autor cede se o contrário resultar da prova dos autos.

A presunção de veracidade deve ser confrontada com a verossimilhança e coerência das demais provas encartadas ao processo para que se chegue a um juízo de valor correto e consentâneo com a realidade material (MOREIRA, 1976). ${ }^{3}$

A falta de defesa deve ser apreciada em cada caso, levando-se em conta a verossimilhança dos fatos aduzidos e a sua coerência com os demais elementos de prova, exercendo o magistrado uma atividade valorativa quanto os elementos constitutivos do direito do demandante e não apenas da presunção advinda como efeito da revelia (MARINONI; ARENHART, 2001). ${ }^{4}$

Por vezes, o próprio autor alega fato impossível ou manifestamente inverossímel, vez que desmentido no decorrer da instrução probatória ou por prova trazida aos autos por ele mesmo (PIMENTEL, 1975, p. $328)^{5}$.

Nestes termos, da inércia do réu decorre a revelia, que traz como conseqüência à imputação da verdade aos fatos articulados pelo autor, salvo se ocorrer qualquer das exceções previstas no artigo 320 do Código

\footnotetext{
${ }^{3}$ Segundo Barbosa Moreira: "Pensem por um momento no caso de o autor afirmar fatos impossíveis, fatos notoriamente falsos, fatos que contradizem outras afirmações feitas pelo próprio autor na sua inicial, fatos manifestamente desmentidos por provas que o próprio autor junte à inicial. Pergunto eu: se algum dos presentes tivesse de julgar uma causa nessas condições, colocaria a verdade formal acima de tudo? Consideraria verdadeiro um fato impossível, ou um fato notoriamente falso, ou um fato contraditório com outras afirmações do autor, pela simples circunstância de ter o réu ficado revel?”

${ }^{4}$ Ilustrativo o exemplo colacionado por Marinoni e Arenhart: "Imagine-se, por exemplo, que o autor, instruindo a petição inicial em que demanda a cobrança de uma divida, faz juntar documento totalmente contrário a seu interesse e que demonstra o pagamento da dívida pelo réu; ainda que o réu seja revel, o juiz certamente há de considerar a presença do comprovante de pagamento e, com isso, afastar a incidência da presunção legal.”

${ }^{5}$ Neste sentido, Pimentel afirma que: "todo e qualquer fato alegado em justiça, contrário ao estado normal ou habitual das coisas, ou a uma situação adquirida, deve ser provado".
} 
de Processo Civil ou em se tratando de fatos desprovidos do atributo da credibilidade, quando, então, apesar de não contestados pelo réu, não serão tidos como verdadeiros (FORNICACIARI, 1977).

É certo que a revelia desonera o autor de provar os fatos que aduziu na inicial, "mas segundo a ratio legis, isto é, a ausência de contestação apenas significa que o autor fica dispensado de provar suas alegações, que, contudo, poderão ser recusadas quando forem absurdas, inverossímeis ou contrárias ao conjunto dos autos" (LOPES, 2000, p. 75).

Portanto, antes de aplicar os efeitos da revelia, cabe ao juiz aquilatar o binômio da verossimilhança e credibilidade dos fatos que serão presumidos como verdadeiros (ALVIM, 1997).

\subsection{Intervenção do revel no processo}

Verificada a revelia, o revel não poderá mais oferecer contestação à pretensão do autor, vez que preclusa sua oportunidade para tanto, mas nada impede que ele venha intervir no processo em qualquer fase.

Ressalta-se que o réu não deixará de ser revel com o seu comparecimento tardio no processo, nem poderá renovar fases processuais já superadas, pois é apenado com sua inserção no processo tal qual se encontre.

O réu continuará sendo revel, porém deverá ser intimado de todos os atos processuais subseqüentes, em estrita observância ao princípio do contraditório e da ampla defesa, sob pena de nulidade do ato.

Não há que se falar em duração da revelia, pois o fato objetivo do não atendimento ao chamado judicial já se consumou no processo, mas sim em um revel atuante, diferentemente do revel ausente (CARRIDE, 2000).

Se oportuna sua intervenção no processo, vez que não superada a fase processual, o revel atuante poderá produzir provas, inquirir testemunhas, participar da prova pericial indicando assistente técnico e quesitos, impugnar o laudo pericial, apontar nulidades ou inépcia da petição inicial, fazer alegações finais, interpor recursos, ou seja, participar e praticar todos os atos que não estejam preclusos até aquele momento. 
Com a intervenção do revel no processo dá-se a cessão do efeito temporário da revelia disposto no artigo 322 do Código de Processo Civil, primeira parte, consistente no escoamento dos prazos independentemente de intimação, pois "ingressando no processo o revel poderá praticar todos os atos dali para frente. Não há restrição" (GIANESINI, 2003, p. 228).

Quando do seu ingresso tardio no processo, o revel poderá carrear aos autos contestação intempestiva, cujo desentranhamento pelo juiz não se mostra razoável.

Ora, o efeito material da revelia de confissão ficta abrange apenas as matérias fáticas, pelo que o revel poderá a qualquer momento argüir questões jurídicas, que deverão ser analisadas pelo magistrado na sua integralidade.

Se a revelia alcança apenas os fatos e não o direito, e a contestação comporta tanto alegações de fato quanto de direito, não tem suporte legal a decisão que manda desentranhá-la, porque a par da confissão ficta que resulta da sua extemporaneidade, cabe ao juiz, inobstante a revelia, analisar as questões jurídicas, inclusive aquelas que tenham sido objeto de alegação do réu, e que, se desentranhada, não lhe proporcionará um exame com a extensão e profundidade pretendidas pela defesa (ALVIM, 2002).

Seria um contra-senso desentranhar a contestação intempestiva e aguardar, posteriormente, a manifestação do revel, através de petição, no que atine a matéria de direito.

Realmente a matéria fática não poderá ser contestada, já que a oportunidade para tanto decorreu, pelo que o juiz não levará em consideração a argumentação do revel neste sentido, restringindo sua análise as questões jurídicas aventadas na contestação intempestiva.

A matéria fática resta incontroversa na revelia, não se admitindo que a intervenção do revel opere efeitos ex tunc, sob pena de se viabilizar a renovação de fases processuais preclusas, mas nem por isso a contestação intempestiva deve ser desentranhada do processo. Válido o ensinamento de Dinamarco:

Não estou a sustentar que essa contestação produzisse todos os efeitos ordinários de uma resposta regular, inclusive o de tornar 
controvertidos os fatos alegados pelo autor. Isso, não. Mas, respeitada sempre a presunção ditada pelo art. 319, a manutenção da peça de resistência poderá ser utilizada em prol dos verdadeiros objetivos do processo justo e équo, a que alude a doutrina mais moderna (Luigi Paolo Comoglio, Augusto Mario Morello), na medida em que (a) alertará o juiz em relação a eventuais fatos impossíveis ou improváveis alegados na petição inicial e (b) esclarecerá seu espírito quanto a dispositivos de lei, conceitos amadurecidos com doutrina, linhas jurisprudenciais estabelecidas nos tribunais do país, etc. (DINAMARCO, 2000, p. 954).

No que atine aos documentos carreados aos autos com a contestação intempestiva, não se exclui o exame dos mesmos, desde que sejam apresentados antes do encerramento da instrução probatória, quando a fase processual restaria preclusa (ASSIS, 2001). ${ }^{6}$

Tanto a defesa quanto os documentos que a instruem devem ser simultaneamente apresentados ${ }^{7}$, porém o juiz pode valer-se de seus poderes instrutórios e mantê-los nos autos, pois não há que se coadunar com a ostentação de um direito inexistente, fruto de presunção, em detrimento do compromisso de entregar a tutela jurisdicional a quem tiver razão.

\subsection{Iniciativa probatória e prova na revelia}

Via de regra, a parte que alegou um fato, seja constitutivo, impeditivo, extintivo ou modificativo, tem o ônus de prová-lo no decorrer da instrução probatória do processo.

Quando da decisão judicial acerca do conflito, o magistrado irá sopesar quem tinha o ônus e logrou êxito na prova para, então, dar provimento a uma das pretensões, seja do autor ou do réu, solucionando a lide.

\footnotetext{
${ }^{6}$ Araken de Assis critica o desentranhamento da contestação e dos documentos que a instruem: "O desentranhamento da contestação e dos documentos produzidos pelo réu, no caso de revelia, constitui sugestivo exemplo de seu mau uso, agravando, desnecessariamente, a posição já desconfortável do revel no direito pátrio".

${ }^{7}$ Neste sentido o artigo 396 do Código de Processo Civil: "Compete à parte instruir a petição inicial (art. 283), ou a resposta (art. 297), com os documentos destinados a provar-lhe as alegações”.
} 
Por seu turno, a ausência de defesa tempestiva torna incontroversos os fatos aduzidos pelo autor, ante a presunção de veracidade que repousa sobre os mesmos, não convertendo as alegações contidas na petição inicial em questões de fato a serem debatidas no decorrer do processo.

Com a revelia o ônus da prova se inverte, já que os fatos constitutivos do direito do autor presumem-se provados, cabendo ao revel lançar dúvidas no espírito do julgador a fim de comprovar a sua inveracidade.

Nada impede que o revel seja atuante e intervenha no processo a qualquer tempo, recebendo-o no estado em que se encontra, procedendo e acompanhando a prova dos fatos que sejam pertinentes e oportunos à causa.

De acordo com o art. 322 do CPC, o revel pode intervir no processo a qualquer tempo, colhendo-o na fase em que se encontra. Ao intervir, poderá o revel, a partir de sua manifestação, provocar dúvida no espírito do julgador sobre a existência do fato constitutivo do direito do autor e, com base nisso, protestar pela produção de prova, que, se o juiz entender necessária para formação do seu convencimento, deverá ser deferida (MEDEIROS, 2003, p. 148).

Contudo, é certo que o revel não poderá alegar fatos impeditivos, modificativos ou extintivos, pois deveria tê-lo feito na contestação, mas quanto aos fatos constitutivos do direito do autor poderá participar da prova, requerendo o que entender conveniente, desde que o momento processual não esteja precluso, isto é, não tenha ocorrido o encerramento da instrução probatória do processo (TALAMINI, 1998). ${ }^{8}$

\footnotetext{
${ }^{8}$ No mesmo sentido Eduardo Talamini: "a revelia não suprime a cognição exauriente. Há a sentença depois de possibilitado o contraditório - e a sentença pode até se amparar em provas produzidas de ofício, não exclusivamente documentais. Não se exclui, além disso, o comparecimento tardio do revel para inclusive produzir provas destinadas a demonstrar a inexistência dos fatos constitutivos do direito do autor e mesmo a existência de fatos embasadores de objeções (fatos impeditivos, extintivos ou modificativos conhecíveis de ofício e, conseqüentemente, alegáveis a qualquer tempo)".
} 
Assim, as provas requeridas pelo revel devem limitar-se aos fatos afirmados na petição inicial, pois ele não poderá fazer prova de alegações que sequer formulou tempestivamente.

Sobre os limites da produção de prova pelo revel, leciona Rita Gianesini:

Um temporal, preclusão do prazo para requerer a sua proposição ou para produzi-la. O pedido de realização de prova poderá, porém, ser suprido pelo formulado pelo autor e deferido, ou pela determinação de ofício do magistrado, ou por motivos supervenientes. O segundo limite relativo ao conteúdo da prova é que deverá cingir-se aos fatos deduzidos pelo autor na inicial (GIANESINI, 1977, p. 123).

A iniciativa probatória do revel atuante deve, então, observar dois limites: temporal e de conteúdo, pelo que a fase probatória não pode estar preclusa e a matéria fática debatida não pode ser alargada além do que o autor aduziu nos autos. Mas, os limites existentes para a iniciativa probatória do revel não podem ser exigidos do magistrado, na busca da verdade real.

Delimitada a lide, com a pretensão apresentada pelo autor, ainda que o réu esteja inerte, o juiz pode se fazer valer de todos os meios de prova que lhe forem convenientes para encontrar a justa composição do litígio, tal qual preconiza o artigo 130 do Código de Processo Civil.

A postura ativa do juiz, visto como diretor material do processo, o impulsiona a tomar todas as provas que se fizerem necessárias para julgar o processo com justiça, mesmo na revelia, atendendo a função social do provimento jurisdicional.

Poderá, o magistrado, reabrir a instrução processual e determinar as provas que lhe pareçam convenientes, ainda que o revel esteja ausente, visando compor o litígio de acordo com a realidade vivenciada no plano do direito material.

Embora tenha se verificado a revelia, o julgamento antecipado do processo nem sempre ocorrerá, principalmente no caso da inexistência de verossimilhança e credibilidade dos fatos presumidos como verdadeiros. 
O julgamento antecipado da lide só se mostra cabível quando os elementos constantes dos autos sejam suficientes para tanto, de maneira a autorizar ao juiz proferir sentença de mérito sem que outras provas sejam produzidas, "o pressuposto geral e inafastável nas três hipóteses autorizadoras do julgamento antecipado é a desnecessidade de produção de qualquer outra prova” (TALAMINI, 1986, p. 93).

\section{PERSUASÃO RACIONAL DO JUIZ: Fundamentação da Decisão e Revelia; Conseqüências da Insuficiência de Motivação}

\subsection{Fundamentação da decisão e revelia}

Embora a Constituição Federal no artigo 93, inciso IX faça expressa menção à necessidade de fundamentação das decisões, a legislação processual ordinária apenas impõe como requisito essencial da sentença a motivação do julgado (artigo 458, inciso II do Código de Processo Civil), sem indicar o conteúdo mínimo e suficiente para tanto.

O Código de Processo Civil limita-se na exigência de um modelo formal de decisão, onde conste uma parte descritiva (relatório), justificativa (fundamentação) e propriamente decisória (dispositivo).

É certo que a fundamentação deve ser completa, clara e precisa, nada impedindo a sua concisão, desde que não haja insuficiência de motivação. "A sentença com fundamentação sucinta, todavia, não deverá ser confundida com a sentença deficiente, incompleta em sua fundamentação" (CARNEIRO, 1996, p. 21).

A fundamentação deve abortar as questões de fato e de direito que sejam relevantes para a solução do litígio e que foram ou deveriam ter sido debatidos no processo.

O juiz deve encontrar "os pontos relevantes para a decisão, ou seja, os pontos prejudiciais: aqueles que serviram de antecedente lógico-jurídico para formar a cadeia de seu raciocínio em direção a decisão final" (PERO, 2001, p. 80).

Justamente sobre os pontos relevantes da lide é que o juiz deve se pronunciar e externar seu convencimento na fundamentação da decisão, assentado nos elementos de fato e de direito constantes dos autos. 
Inexiste forma predeterminada para que o juiz analise os fatos e o direito, vez que livre o seu convencimento, o que importa é que seja suficientemente fundamentado, principalmente quanto aos pontos cruciais da controvérsia. Afinal, "[...] se toleram na sentença eventuais omissões de fundamentação no tocante a pontos colaterais ao litígio, pontos não-essenciais ou de importância menor, irrelevantes ou de escassa relevância para o julgamento. $\mathrm{O}$ que não se tolera são as omissões no essencial” (PERO, 2001, p. 81). ${ }^{9}$

O sistema processual admite até mesmo duas decisões divergentes sobre a mesma questão, desde que elas contenham uma motivação racional devidamente exteriorizada para que se exerça o controle endo e extraprocessual da tutela jurisdicional.

Contudo, a jurisdição não se contenta com decisões genéricas, desprovidas de qualquer suporte de motivação, pois,

A sentença substancialmente fundamentada é a que aprecia todos os pontos relevantes da lide, vez que condicionantes ao julgador, auferidos em cada caso concreto no decorrer do debate processual, para a tomada da sua decisão WATANABE, 2000) ${ }^{10}$.

Da mesma forma, na sentença em que se revolve um conflito onde o réu não respondeu ao chamado judicial na forma e prazos legais, a fundamentação completa é imprescindível, com "interpretação das normas aplicadas, a averiguação dos fatos, a qualificação jurídica da fattispecie e a declaração das conseqüências jurídicas derivantes da decisão" (TARUFO, 1975, p. 450).

Ainda que os efeitos da revelia tenham se operado, restando presumidos como verdadeiros os fatos afirmados pelo autor, a investigação probatória pelo juiz diretor material do processo não

\footnotetext{
${ }^{9}$ Texto cedido por Cândido Rangel Dinamarco e citado por Maria Tereza Gonçalves Pero

${ }^{10}$ Sobre a obrigatoriedade da cognição e motivação, dispõe Kazuo Watanabe: "Na solução de qualquer problema, seja jurídico ou matemático, o fundamental é montar a equação corretamente. $\mathrm{Na}$ equação do problema jurídico, o dado de direito é, evidentemente, de grande importância, mas relevância superlativa tem o dado fático. Analisar bem as provas, avaliando corretamente os fatos, não se deslembrando o juiz, jamais, da advertência alhures feita de que o 'profissional do direito (juiz, advogado ou promotor) não se deve envergonhar de lidar com fatos, pois o direito nasce dos fatos', é condição fundamental para a prática da justiça”.
} 
está descartada, podendo ser exercida para que ocorra a sua persuasão e como forma de encontrar uma fundamentação substancial a decisão.

Assim, é através do livre convencimento racional ou motivado que o juiz afere a verossimilhança ou não dos fatos articulados pelo autor, na petição inicial, caso o réu incida em revelia e não ocorra nenhuma das excludentes do artigo 320 . Se a presunção advinda da revelia fosse iuris et de iuris, não poderia ser aplicado o sistema mencionado; mas, então, haveria aberração tamanha, a ponto de o direito processual vir a "criar" direito que a parte não tem. Por outro particular, o fato alegado pelo autor pode ser juridicamente impossível ou mesmo fisicamente impossível, o que viria em descrédito do Poder Judiciário (CARRIDE, 2000, p. 104).

A motivação não pode ser distorcida da realidade fática, mesmo na revelia, que embora importe em algum prejuízo ao revel não pode ser sinônimo de decisão desprovida de fundamento coerente e razoável, para que se cumpra a função endo e extraprocessual do julgado.

Embora na revelia ocorra uma aceleração ou simplificação do procedimento, a tutela jurisdicional a ser prestada deve ser fruto de uma cognição plena e exauriente (WATANABE, 2000). ${ }^{11}$

Nas ações de conhecimento, ocorrendo os efeitos da revelia (total ou parcial; cf. arts. 319 e 320 do CPC), e, assim também, nos casos em que não há impugnação específica dos fatos que constituem a pretensão do autor (cf. art. 302 do $\mathrm{CPC}$ ), não há, propriamente, cognição sumária, mas cognição plena e exauriente sobre o objeto litigioso. Com efeito, nem sempre a ausência de contestação gerará a procedência do pedido. Pode ocorrer que o fato afirmado na petição inicial seja inverossímil, ou que as conseqüências jurídicas pretendidas não decorram, necessariamente, dos fatos tidos por verdadeiros. O juiz terá diante de si apenas o fenômeno da indiscutibilidade (relativa, cf. incisos dos atrs. 302 e do 320 do $\mathrm{CPC}$, conforme o caso) dos fatos, razão pela qual poderão ter sua

\footnotetext{
${ }^{11}$ Vale lembrar que: "[...] a solução definitiva do conflito de interesses é buscada através de provimento que se assente em cognição plena e exauriente, vale dizer, em procedimento plenário quanto à extensão do debate das partes e da cognição do juiz, e completo quanto à profundidade dessa cognição".
} 
prova dispensada pelo juiz (cf. art. 334, III e IV, do CPC). Mas, daí dizer que a cognição realizada pelo juiz seria sumária há uma enorme distância. Ora, tanto a cognição não é sumária que o juiz pode não ter como crível o fato, embora não contestado, e isso ele constatará examinando-o (o que é nítida demonstração de que a cognição é exauriente). Assim, a cognição é plena e exauriente, nos limites daquilo que é oferecido pelas partes ao juiz, para que este conheça. A sentença aí proferida, deste modo, é acobertada pela coisa julgada (WAMBIER, 1997, P. 124-125).

Ora, o magistrado não pode admitir como verdadeiros na decisão fatos diversos daqueles vivenciados, distanciando-se do direito material, em descrédito do Judiciário, por deixar de efetuar a cognição adequada.

A insuficiência de motivação na sentença decorre da falta de cognição plena e exauriente sobre a matéria do processo, ainda que incontroversos os fatos, ante a revelia.

Os fatos alegados pelo autor somente serão reputados verdadeiros se o contrário não resultar da prova do processo, cabendo ao juiz exercer o seu poder instrutório para compor adequadamente a lide, concedendo o direito à parte que fizer jus e não aquela que apenas se beneficiou da inércia do revel.

O que se evidencia, tanto na doutrina, quanto na jurisprudência, é que o rigor da regra do art. 319 do CPC tem sido atenuado por interpretação que se faz dessa regra à luz do princípio da ampla defesa e do contraditório, assegurados constitucionalmente, e do livre convencimento motivado, de maneira a não se impor ao juiz que, mesmo em face de dúvida séria a respeito de como os fatos se passaram - dúvida resultante da simples leitura da petição inicial ou da análise de elementos constantes dos autos -, tenha que julgar a favor do autor, porque, por ficção legal, esses fatos não impugnados reputam-se verdadeiros (MEDEIROS, 2003, P. 118).

O juiz não pode aceitar fatos absurdos, devendo cercar a revelia da relatividade que lhe é inerente. Verificar, na fundamentação da decisão, o binômio da verossimilhança e credibilidade dos fatos que serão presumidos como verdadeiros é tarefa do juiz para poder expedir uma motivação suficiente do julgado, mesmo no caso do revel ausente. 
A motivação suficiente deve se dar, também, quanto à matéria de direito, já que na revelia a presunção relativa circunscreve-se aos fatos aduzidos pelo autor, cabendo ao juiz a correta aplicação da norma jurídica abstrata ao caso concreto.

Destarte, o juiz não pode alterar a causa de pedir, sob pena de julgamento extra ou ultra petita, mas as razões de direito indicadas na petição inicial podem ser diversas na motivação da decisão, sem qualquer violação a sistemática processual, com o efetivo e correto enquadramento do fato à legislação.

Nada impede a motivação concisa na revelia, mas deverá ser suficiente quanto à matéria fática (verossimilhança e credibilidade dos fatos) e jurídica (norma aplicável).

Não se espera que o magistrado de hoje se demore a elaborar longas decisões - o que nunca foi necessário -, com as quais os tempos já não se coadunam. Entretanto, mesmo a mais sucinta das decisões deverá obrigatoriamente deixar clara a relação de pertinência lógicojurídica entre os elementos constantes dos autos, a norma jurídica aplicada e o decisum, sob pena de incorrer no vício da omissão (PERO, 2001, p. 116).

Ademais, o revel atuante, ao intervir no processo, pode trazer pontos relevantes para a decisão, que devem ser analisados e sopesados pelo juiz na decisão do conflito, sob pena da incompletude da tutela jurisdicional.

\subsection{Conseqüências da insuficiência de motivação}

A falta de motivação acerca de todos os pontos relevantes da lide, por servirem de antecedente para a formação da convicção do julgador, traduz-se na insuficiência de fundamentação. A sentença insuficientemente fundamentada ou incompleta em sua fundamentação é a que o juiz não apreciou determinada questão relevante para a solução do conflito.

Justamente por restar incompleta na sua fundamentação, a decisão padece de vício, consistente na ausência de suficiente motivação dos pontos cruciais do julgado, que é um dos seus elementos essenciais, conforme preceitua o artigo 458 do Código de Processo Civil. 
Trata-se de vício intrínseco da sentença, destacados em três espécies por Teresa Arruda Alvim: a) ausência de fundamentação, b) deficiência de fundamentação e c) ausência de correlação entre fundamentação e decisório; que, conclui, serem todos redutíveis na ausência de fundamentação, isto porque "fundamentação deficiente, em rigor, não é fundamentação, e, por outro lado, 'fundamentação' que não tem relação com decisório, não é fundamentação: pelo menos não o é daquele decisório" (ALVIM, 1993, p. 200).

Cabe observar que existe motivação na sentença mal fundamentada, vez que ela se manifestou sobre os pontos cruciais da lide, mesmo que de forma deficiente, pois o sistema processual não exige que a fundamentação seja correta, limitando-se em indicar a necessidade da sua coerência e exteriorização pelo julgador.

No caso da sentença completa, mas mal fundamentada, cabe a parte sucumbente manejar no tempo e forma hábeis o recurso correspondente, utilizando-se do duplo grau de jurisdição para suprir a deficiência do julgado, seja nas questões de fato ou de direito.

Da mesma forma, a sentença sucintamente fundamentada não contêm vício essencial, já que não se confunde com a sentença com motivação deficiente.

Por seu turno, para a decisão onde não exista fundamentação, o que engloba aquela insuficientemente fundamentada, a própria Constituição Federal, fugindo da sua regra de enumerar normas meramente principiológicas (NERY JUNIOR, 2002), cominou pena expressa de nulidade, nos termos do artigo 93, inciso IX.

Assim, "não são só, portanto, as decisões judiciais carentes de fundamentação que afrontam a Constituição Federal, mas também, as insuficientemente fundamentadas" (NOJIRI, 1998, p. 140).

Não há que se falar em inexistência da decisão, já que ela produzirá efeitos até que seja declarada a sua nulidade, "não impedindo inclusive que a parte vencida espontaneamente venha a cumpri-la ou que a parte vencedora promova sua execução" (PERO, 2001, p.123).

Para Liebman (1984) o ato nulo, apesar do vício que carrega, existe na sua identidade e com a sua fisionomia particular, produzindo efeitos que lhe são próprios; enquanto no ato inexistente faltam os traços mínimos e essenciais, devendo juridicamente ser considerado como um nada, tal qual uma sentença judicial proferida por alguém que não é juiz ou se faltar um documento escrito para tanto. 
A decisão não fundamentada existe, mas é nula, por não cercar a tutela jurisdicional em todos os seus pontos relevantes para o efetivo desfecho do conflito. Assim, a decisão judicial sem fundamentação suficiente, apesar de conter vício essencial, é válida até ser declarada nula.

A sentença carente de motivação transitará em julgado, mas pode ser desconstituída no biênio posterior à formação da coisa julgada (WAMBIER, 1998, p. 164-165), cabendo a parte manejar a ação rescisória com fulcro no inciso V do artigo 485 do Código de Processo Civil.

No caso, a violação a literal disposição de lei deve ser entendida em sentido amplo, abrangendo as normas processuais e a própria Constituição Federal (NERY JUNIOR; NERY, 1997), já que a decisão não terá atendido a disposição contida no artigo 458, III e 165 do Código de Processo Civil, além do artigo 93, inciso IX da Constituição Federal.

Em se tratando de nulidade absoluta a parte pode alegar a qualquer momento o vício processual, seja em sede recursal, inclusive embargos de declaração, ou por meio de ação rescisória, podendo o juiz conhecer e declará-la de ofício.

A sentença insuficientemente fundamentada ou incompleta em sua fundamentação no processo onde ocorreu à revelia também padecerá de nulidade absoluta, que poderá ser reconhecida pelo juiz de ofício ou mediante manifestação do revel atuante, ainda que apenas quando do manejo da ação rescisória, ante o transito em julgado da decisão.

\section{CONCLUSÕES}

A revelia acarreta efeitos negativos, fruto da inércia, consagradas na presunção de veracidade dos fatos afirmados pelo autor na inicial (efeito material), bem como na desnecessidade do revel ser intimado dos atos processuais subseqüentes até sua futura intervenção no processo (efeito processual).

Contudo, o fato objetivo da revelia nem sempre acarreta automaticamente os seus efeitos, principalmente o material, ante a falta de verossimilhança e coerência dos fatos a serem presumidos como verdadeiros. 
A presunção relativa na revelia não engloba, ainda, a matéria de direito $^{12}$, que deve ser analisada pelo magistrado na sua integralidade, podendo, inclusive, o revel ao integrar a lide, apresentar questões jurídicas a serem apreciadas pelo juiz.

Outrossim, observa-se que se dispensa apenas a intimação do revel dos atos processuais, mas os prazos para ele devem ser respeitados, não se retirando à oportunidade do seu ingresso no processo posteriormente.

O revel atuante não poderá mais oferecer contestação à pretensão do autor, vez que preclusa sua oportunidade para tanto, já que ele continuará revel. Mas, o revel pode participar e deve ser intimado dos atos processuais posteriores ao seu ingresso, sendo defeso apenas renovar fases processuais já superadas.

Cabe ao revel, se houver tempo para isso quando do seu ingresso no processo, lançar dúvidas no espírito do julgador a fim de provar a inveracidade das alegações do autor, vez que com a revelia o ônus da prova se invertem, pois os fatos constitutivos do direito do demandante presumem-se provados.

A iniciativa probatória do revel atuante deve, então, observar dois limites: temporal e de conteúdo, pelo que a fase probatória não pode estar preclusa e a matéria fática debatida não pode ser alargada além do que o autor aduziu nos autos.

Por fim, quando da fundamentação da decisão, o juiz, para possibilitar o controle dos atos jurisdicionais (endo e extraprocessual), terá que exteriorizar o seu livre convencimento, atendendo, assim, ao princípio da persuasão racional, mostrando a coerência e fundamentação da decisão, tanto das bases fáticos quanto jurídicas.

A decisão deve ser completa, sendo que justamente sobre os pontos relevantes da lide é que o juiz deve ser pronunciar e externar seu convencimento na fundamentação da decisão, assentado nos elementos do fato e de direito constante nos autos. Da mesma forma, a sentença que envolve conflito onde o réu não respondeu ao chamado judicial na forma e prazos legais a fundamentação completa é imprescindível.

\footnotetext{
${ }^{12}$ Artigo 319 do Código de Processo Civil: "Se o réu não contestar a ação, reputar-seão verdadeiros os fatos afirmados pelo autor" (grifo nosso).
} 
Tolera-se a decisão concisa, mas não a insuficientemente fundamentada, pois a tutela jurisdicional na revelia também deve ser fruto de cognição pela e exauriente.

Verificar, na fundamentação da decisão, o binômio da verossimilhança e credibilidade dos fatos que serão presumidos como verdadeiros é tarefa do juiz para poder expedir uma motivação suficiente do julgado, mesmo no caso do revel ausente.

A decisão não fundamentada existe, mas é nula, por não cercar a tutela jurisdicional em todos os seus pontos relevantes para o efetivo desfecho do conflito, padecendo, assim, de vício intrínseco.

\section{REFERÊNCIAS}

ALVIM, J. E. Carreira. Conseqüências fática e jurídicas da revelia. Contestação intempestiva. Impossibilidade de desentranhamento. Jus Navegandi, n. 56. Disponível em: 〈http://www1.jus.com.br/doutrina/texto.asp?id=2916〉. Acesso em: 16/out./2002.

BAPTISTA DA SILVA, O. A. Curso de Processo Civil - Processo de Conhecimento. São Paulo: Revista dos Tribunais, 2000.

BARBI, C. A. Comentários ao Código de Processo Civil. Rio de Janeiro: Forense, 1997.

BELINETTI, L. F. Sentença Civil: perspectivas conceituais no ordenamento jurídico brasileiro. São Paulo: Revista dos Tribunais, 1994.

BEDAQUE, J. R. dos S. Poderes Instrutórios do Juiz. São Paulo: Revista dos Tribunais, 2001.

CHIOVENDA, G. Instituições de Direito Processual Civil. Campinas: Bookseller, 1998.

CAMBI, E. Direito Constitucional à Prova no Processo Civil. São Paulo: Revista dos Tribunais, 2001.

CAPpelletTI, M. La oralidad y Las Pruebas em el Proceso Civel. Buenos Ayres: EJEA, 1972.

CARNEIRO, A. G. Sentença Mal Fundamentada e Sentença Não Fundamentada. RePro n⿳亠丷 81. São Paulo, p. 220, jan./mar./1996.

CARRIDE, N. de A. Revelia no Direito Processual Civil. Campinas: Copola, 2000.

DINAMARCO, C. R. Instituições de Direito Processual Civil. São Paulo: Malheiros, 2001. 
, Ônus de Contestar e o Efeito da Revelia. RePro n. 41. São Paulo. Jan/mar/1996.

FEREIRA FILHO, M. C. A preclusão no direito processual civil. Curitiba: Juruá, 1991.

FORNICACIARI, C. Reconhecimento Jurídico do Pedido. São Paulo: Revista dos Tribunais, 1977, p. 1).

GIANESINI, R. Da Revelia no Processo Civil Brasileiro. São Paulo: Revista dos Tribunais, 1977.

. Revelia. RePro n. 109. São Paulo, p. 228. jan./mar./2003.

GRECO FILHO, V. Direito processual civil brasileiro. São Paulo: Saraiva, 1999.

LIEBMAN, E. T. Manual de Processo Civil (traduzido e anotado por Cândido Rangel Dinamarco). Rio de Janeiro: Forense, 1984.

MARINONI, L. G.; ARENHART, S. C. Manual do Processo de Conhecimento. São Paulo: Revista dos Tribunais, 2001.

MEDEIROS, M. L. L. C. A Revelia sob o Aspecto da Instrumentalidade. São Paulo: Revista dos Tribunais, 2003.

MOREIRA, J. C. B. A resposta do réu no sistema do Código de Processo Civil. RePro 2. São Paulo. Dez/jan/1976.

NERY JUniOR, N. NERY, R. M. de A. Código de Processo Civil comentado e legislação processual civil extravagante em vigor.. São Paulo: Revista dos Tribunais, 2001.

NOJIRI, S. O dever de fundamentar as decisões judiciais. São Paulo: Revista dos Tribunais, 1998.

OlIVEIRA, F. A. de. Manual de Revelia. São Paulo: Revista dos Tribunais, 2002.

PERO, M. T. G. A motivação da sentença civil. São Paulo: Saraiva, 2001.

PORTANOVA, R. Princípios do Processo Civil. Porto Alegre: Livraria do Advogado, 2003.

SALAMACHA, C. Bilateralidade da ação - respeito ao contraditório visando a função social do processo. RePro, n 73. São Paulo, p. 149-150, jan./ mar./1994.

SOUZA, A. C. de. Contraditório e Revelia. São Paulo: Revista dos Tribunais, 2003. 
SOUZA, G. A. de. Da Revelia. RePro n 80. São Paulo, p. 189, out-dez de 1995.

TALAMINI, E. Curso Avançado de Processo Civil. São Paulo: Revista dos Tribunais, 2002, vol. 1, p. 412.

TARUFO, M. La Motivacione della Sentenza Civile. Padova: Cedam, 1975.

TUCCI, R. L. Da contumácia no processo civil brasileiro. São Paulo: Bushatsky, 1964.

WAMBIER, L. R.; ALMEIDA, F. R. C. de A.; TALAMINI, E. Curso Avançado de Processo Civil. São Paulo: Revista dos Tribunais, 2002.

WAMBIER, T. A. A. Nulidades do processo e da sentença. São Paulo: Revista dos Tribunais, 1997.

WATANABE, K. Da Cognição no Processo Civil. Campinas: Bookselles, 2000. 
